\title{
CLINICAL AND PATHOLOGICAL INVESTIGATION OF Nandus nandus COLLECTED FROM FISH MARKETS OF MYMENSINGH
}

\author{
K. Marma, G. U. Ahmed, M. A. R. Faruk and K. Gosh \\ Department of Aquaculture, Bangladesh Agricultural University \\ Mymensingh-2202, Bangladesh
}

\begin{abstract}
An experiment was carried out in order to investigate the health status of Nandus nandus based on clinical and histopathological observation collected from three fish markets of Mymensingh district. The study was conducted for a period of six months from October 2005 to March 2006. Clinically, it was evident that fishes were more affected having scale loss and deep dermal ulceration in the months of December and January, which were observed in Sankipara Railway Crossing and Gollpukurpar markets. But fish appeared almost normal during October to November and February to March collected from the three fish markets. Histopathologically, marked necrosis, pyknosis, haemorrhage, vacuoles and fungal granuloma were observed in skin, muscle and kidney. Gills had monogenetic trematode, hypertrophy and melanomacrophages in December and January. Liver of examined fishes had less pathological signs compared to other organs. However, Nandus nandus was found more affected in Gollpukurpar and Sankipara Railway Crossing markets compared to K-R market. From overall observation, it could be concluded that fishes were severely affected by EUS and dactylogyrosis during the months of December and January.
\end{abstract}

Key Words : N. nandus, Health issues, Fish market, EUS

\section{INTRODUCTION}

Carps and small indigenous fishes are important group of fish, which are being successfully cultured in many countries of the world, particularly in the South East Asian countries. In Bangladesh, there are at least 40 to 50 small indigenous fish species (SIS), which have been defined as species and grow to a maximum length of about $25 \mathrm{~cm}$. (Felts et al., 1996). These fish are commonly referred to as 'Chhotomach' or "miscellaneous species of fish and prawn". Small indigenous freshwater fishes generally grow in open water bodies such as haors, baors, beels, rivers, canals and flood plains with natural care. It has high nutritional value in terms of protein, vitamins and minerals and these vitamins and minerals are not commonly available in other foods (Thilsted et al., 1997). Small fishes contain large amount of calcium and most likely also iron and zinc (Tripathi, 1997). These small fishes were caught by the large number of poor fishermen and provided a major protein intake to the consumers through markets.

The fish market is considered as a place of interaction between the fish seller and consumer. Generally, this place is not so much well developed and well furnished up to 
the consumer's expectation. Moreover, fisherman and intermediaries of Mymensingh district faced a number of problems such as poor transportation, lower price of fish, lack of storage facilities, lack of weighing system, assessment of market tolls, lack of marketing facilities as well as political instability (Khan, 1995). It was also observed that there were not only several weak, injured and diseased fish gathered in the fish markets but also several healthy fish were found and this ratio were also varied on time to time and season to season. On the other hand, there were several reasons behind getting the unhealthy fish where diseases might playing one of the major role.

Disease is one of the most important problem of fish production both in culture system and wild condition of Bangladesh (Rahman and Chowdhury, 1996). EUS outbreak in 1988, Channa sp., Puntius sp., Nandus sp., Mystus sp. and various indigenous species of fish were seriously affected throughout Bangladesh (Barua et al., 1990). As the supplied fish of the markets had different health status, it has become an urgent task for the scientists to investigate on this topic of fish found in the markets. Clinical and histopathological observations may be very helpful in diagnosing fish diseases. This method has been used for disease diagnosis of fishes in a limited extent in Bangladesh (Moniruzzaman, 2000; Ahmed et al., 2000). So, the present work was undertaken in order to study the pathology and diseases of Nandus nandus obtained from different fish markets of Mymensingh through clinical and histopathological observation.

\section{MATERIALS AND METHODS}

The present investigation was conducted for a period of six months from October 2005 to March 2006. The selected experimental fish N. nandus was collected from different fish markets of Mymensingh including Sankipara Railway Crossing Market, Gollpukurpar Market and K. R. Market. Sankipara Railway Crossing Market and Gollpukurpar market, were located at the Mymensingh town, which stands about $5 \mathrm{~km}$ north of Bangladesh Agricultural University Campus. On the other hand, K-R (Kamal - Ranjit) market was located at the Bangladesh Agricultural University campus which was a small single linked market and fishes were available in the morning from $07 \mathrm{AM}$ to $11 \mathrm{AM}$. Nandus nandus was collected from all of the three fish markets twice in a month during the experimental period. Five live fish of each species were collected monthly from each market and immediately carried to the Fish Disease Laboratory of the Faculty of Fisheries, Bangladesh Agricultural University, Mymensingh. The sampled fish were examined thoroughly both by naked eye and magnifying glass to observe any injury, infection or other abnormal condition of the fish body. Skin, muscle, gill, liver and kidney were collected for histopathological study with the help of sharp scalpel and forceps and preserved in $10 \%$ neutral buffered formalin. The preserved samples were taken out, trimmed to a size of $3 \mathrm{~mm}^{3}$. Then the samples were placed in an automatic tissue processor (SHANDON, CITADEL, 1000) for dehydration, clearing and wax infiltration. The samples were then embedded with melted wax, perforated steel mold and plastic holder (Ahmed et al., 2000). Wax embedded tissue blocks were sectioned at a thickness of 5 micrometers by using the microtome. The sections were then stained with 
Haematoxylin and Eosin stains. Then the section were mounted with Canada balsam and covered with a cover slip. To hold the cover slips permanently the prepared slides were placed over a clean platform for 24 hours and then examined under a compound microscope (OLYMPUS). Photomicrographs of the stained sections were taken by using a photomicroscope (OLYMPUS, Model CHS, Japan).

\section{RESULTS AND DISCUSSION}

Clinically, fishes collected from all the markets in October and November had minor sign, which were captured from beel and river (Table 1). During this period N. nandus had skin discoloration, rough skin and mild scale loss. Moniruzzaman (2000) also mentioned that fishes obtained from beels had rough skin, minor red spots and discoloration of skin in October and November. But in December and January severe abrasion, scale loss, weak body, deep ulcer and subcutaneous lesion were recorded for the fishes of all the markets (Table 1). Parveen (2001) examined through clinical, parasitological and histopathological observations of three small indigenous fishes like P. ticto, N. nandus and C. punctatus from four beels of Mymensingh district and found that all fishes were severely affected during December and January. Ahmed and Hoque (1999) also found clinical symptoms like grey white necrotic areas in December, January and February in various carp species of Bangladesh.

Table 1. Clinical signs of affected fishes at different markets in various months

\begin{tabular}{|c|c|c|c|c|c|c|c|}
\hline \multirow[t]{2}{*}{ Species } & Months & \multirow[t]{2}{*}{ October } & \multirow[t]{2}{*}{ November } & \multirow[t]{2}{*}{ December } & \multirow[t]{2}{*}{ January } & \multirow[t]{2}{*}{ February } & \multirow[t]{2}{*}{ March } \\
\hline & Markets & & & & & & \\
\hline \multirow{3}{*}{$\begin{array}{l}\text { Nandus } \\
\text { nandus }\end{array}$} & SRC market & $\mathrm{AN}$ & $\begin{array}{l}\text { SL in some } \\
\text { places }\end{array}$ & $\begin{array}{l}\text { RS \& ulcer } \\
\text { with SL }\end{array}$ & $\begin{array}{l}\text { Dc \& DU in the } \\
\text { body region }\end{array}$ & $\begin{array}{l}\text { rs \& mild } \\
\text { dermal lesion }\end{array}$ & $\begin{array}{l}\mathrm{AN} \& \\
\text { minor WB }\end{array}$ \\
\hline & GPK market & AN & WB \& rs & $\begin{array}{l}\text { WB \& RS in } \\
\text { 'v' \& ' } \mathrm{p}^{\prime} \\
\text { region }\end{array}$ & $\begin{array}{l}\text { Ulcer with SL in } \\
\text { head region in } \\
\text { body }\end{array}$ & $\begin{array}{l}\text { rs \& mild } \\
\text { dermal lesion }\end{array}$ & $\mathrm{AN}$ \\
\hline & K. R. market & HA & $\mathrm{AN} \& \mathrm{WB}$ & RS \& rs & $\begin{array}{l}\text { WB \& SL in some } \\
\text { places }\end{array}$ & $\begin{array}{l}\text { SL in some } \\
\text { places }\end{array}$ & HA \\
\hline
\end{tabular}

$\mathrm{AN}=$ almost normal, $\mathrm{Dc}=$ discoloration, $\mathrm{DU}=$ deep ulcer, $\mathrm{GPK}=$ Gullpukurpar market, $\mathrm{HA}=$ healthy appearance, $\mathrm{K} . \mathrm{R}=$ Kamal-Ranjit market, $\mathrm{p}=$ pelvic, $\mathrm{rs}=$ rough skin, $\mathrm{RS}=$ red spots, $\mathrm{SL}=$ scale loss, $\mathrm{SRC}=$ Sankipara Railway Crossing Market, $\mathrm{v}=$ ventral, $\mathrm{WB}=$ weak body

However, fish of all the markets had minor pathological sign such as weak body, rough skin and mild red spots were observed in February and March. Islam (1999); Monowara (2003); Chakma (2002), also agreed that clinically and histopathologically fishes were found to be less affected during the months of February and March. Thus it could be mentioned here that Sankipara Railway Crossing and Gullpukurpar markets were severely affected compared to K. R. Market.

Histopathologically, it was observed that the investigated fish collected from all the fish markets were almost normal in October and March, whereas minor pathological changes were evident in November and February. But marked pathological changes were 
recorded in December and January and severity of infection gradually decreased during February and March. Among the three markets fish were severely affected in Gollpukurpar market. In N. nandus from Gollpukurpar market, epidermis and dermis were lost, haemorrhages, necrosis, vacuolation and fungal granuloma were observed in the skin and muscle during December to January. Similarly, epidermis and dermis were partially lost having necrosis and vacuoles in case of fish collected from K. R. market. Noga and Dykstra (1986) were of the opinion that marked granulomatus, inflammatory response were shown by fish infected with Aphanomyces sp. Hatai et al. (1994) also reported fungal hyphae and several granulomas in the internal organs and musculature of EUS affected Colisa lalia in Japan. Akter et al. (2006) and Roy et al. (2006) found fungal hyphae and huge granulomas in the skin and muscle of some small indigenous fish species of Mymensingh district.

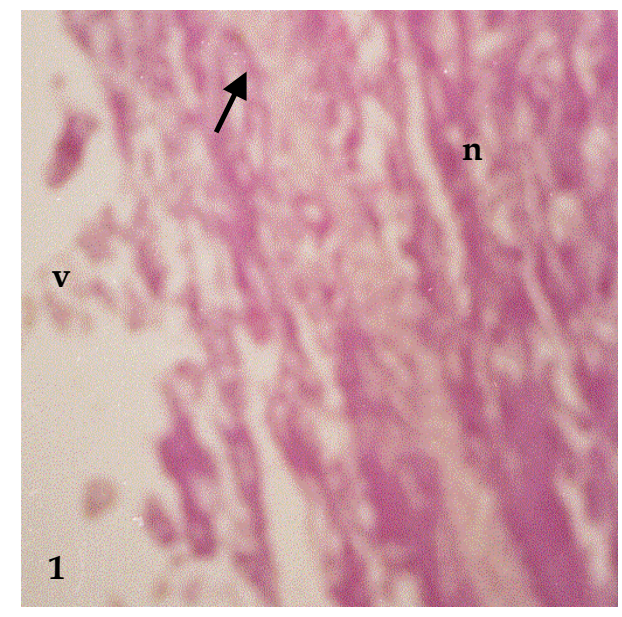

Fig. 1. Section of skin \& muscle of N. nandus in October \& November from K-R market. Epidermis partly lost (?), dermis missing, necrosis (n), vacuole (v) were present. H \& E x 125.

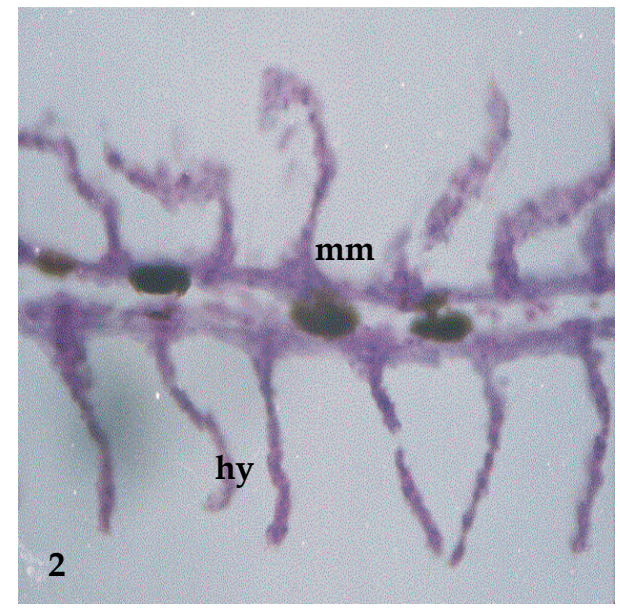

Fig. 2. Section of gill of N. nandus in October \& November from K-R market. Primary \& secondary gill lamellae were almost normal but melanomacrophages $(\mathrm{mm}) \&$ hyperplasia (hy) were seen. H \& E x 440.

However, gills were more affected compared to other organs. Both the gill lamellae had hyperplasia, haemorrhage, melanomacrophage and partially lost in some places having monogenetic trematodes in N. nandus collected from Sankipara Railway Crossing market during the months of December and January. Similar results were also found by Ahmed et al. (1998) in juvenile Indian major carps. Necrosis, pyknosis clubbing, hypertrophy and hyperplasia were also found by Ahmed and Hoque (1998); Islam (1999); Moniruzzaman (2000) in the gill of freshwater fishes of Bangladesh. Internal organ such as liver were also affected during the months of December and January.

N. nandus liver had marked necrosis, vacuoles, pyknosis during December and January from K. R. market. Mild pathology and fat body were observed in November and February in fish collected from Sankipara Railway Crossing and Gullpukurpar markets. 
Ram and Singh (1988) found similar pattern and degree of pathological changes in liver. Kumar et al. (1991) observed severe pathological changes in the skin, muscle, kidney, liver and heart of EUS affected Puntius, Mastacembelus and Channa in India. Akter at el. (2006) also reported that internal organs such as liver and kidney were affected in the fishes collected from Ailee beel.

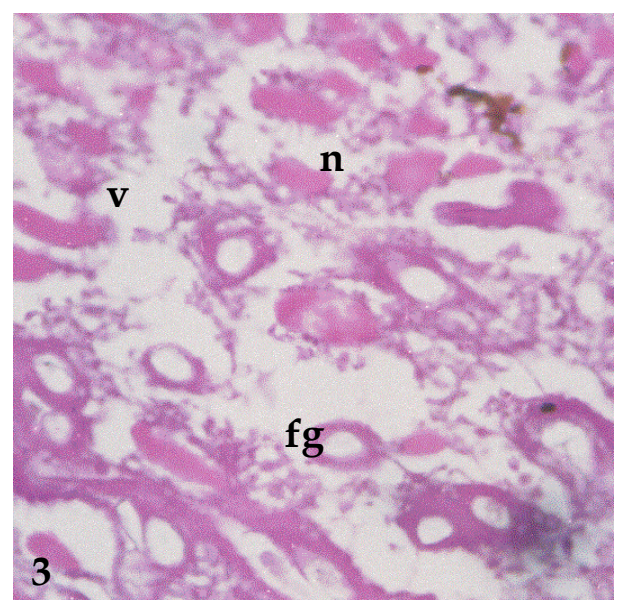

Fig. 3. Section of skin \& muscle of $N$. nandus in December \& January from GPK market. Muscle necrotic (n), fungal granuloma (fg) and vacuums (v) were seen. H \& E x 440.

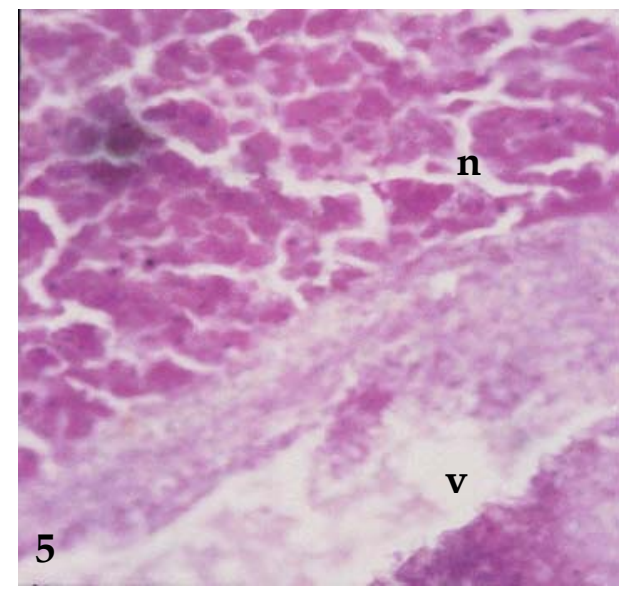

Fig. 5. Section of liver of $N$. nandus in December \& January from K-R market. Severe necrosis (n) \& vacuoles (v) were seen. H \& E x 440.

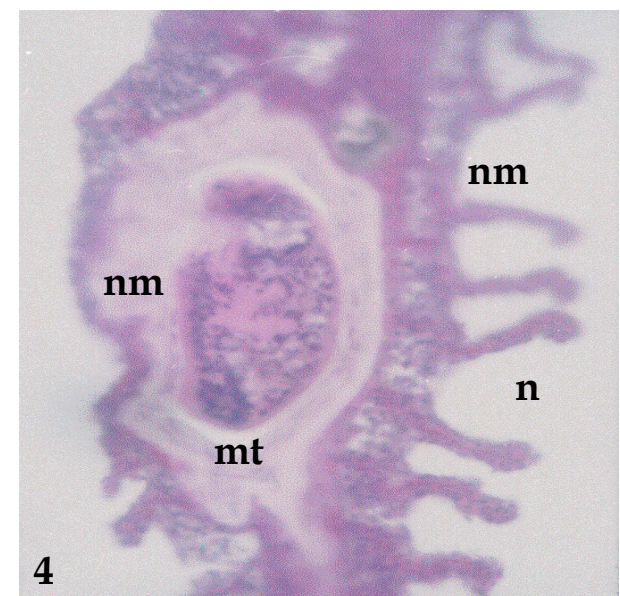

Fig. 4. Section of gill of N. nandus in December \& January from GPK market. Primary \& secondary gill lamellae were lost \& necrosis (n), melanomacrophages (mm) \& a monogenetic trematode $(\mathrm{mt})$ were found. H \& E x 440.

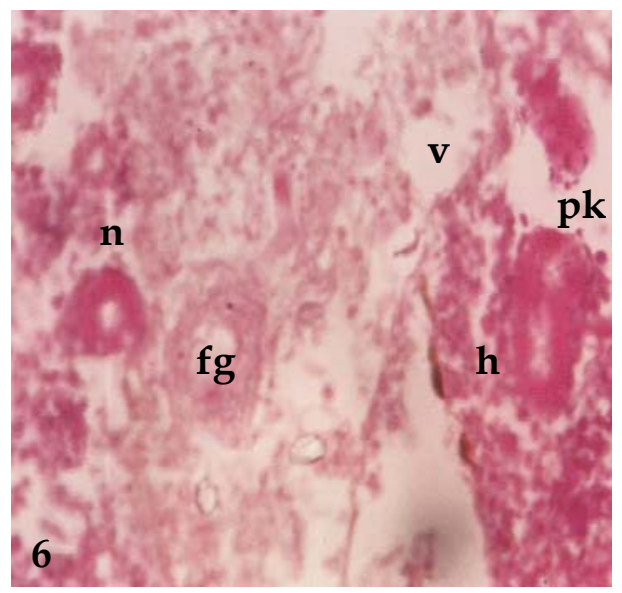

Fig. 6. Section of kidney of N. nandus in December \& January from GPK market. Necrosis (n), pyknosis (pk), vacuoles (v), haemorrgahe (h) \& fungal granuloma (fg) were seen. H \& E x 440. 
Kidney of N. nandus were found to have severe necrosis, pyknosis, haemorrhage, vacuoles and fungal granulomas during the months of December and January in fish collected from Gullpukurpar market (Fig. 6). Mild haemorrhage and vacuoles were observed in the months of October and March from Sankipara Railway Crossing and K.R. markets. Similar pathological signs and symptoms of kidney of major carp were observed by Ahmed and Hoque (1999); Islam (1999); Moniruzzaman (2000). Ahmed and Hoque (1999) reported that histopathologically the internal organs like kidney and liver were more affected and disease like EUS occurred during the months of December and January. From the results it could be mentioned that $N$. nandus was severely affected with EUS occurred during the months December and January. Roy et al. (2006) observed that kidney tubules were necrotic having wide vacuoles, blood cell, other inflammatory cells and pyknotic cells were the pathological changes in C. punctatus during the months of December and January. Akter et al. (2006) found similar results in kidney of small indigenous species.

The study showed that the external organs like skin, muscle and gills were more affected than the internal organs like liver and kidney in all the fish markets. Similar results were also observed by Ahmed et al. (2004) in small indigenous fishes from Kailla beel of Mymensingh. Ahmed et al. (2004) mentioned that external organs like skin and gill were more affected than the internal organs such as liver and kidney.

From the present study it was observed that, N. nandus was a severely affected fish collected from Gullpukurpar market and Sankipara Railway Crossing market, whereas fishes of K. R. market were observed to have less affected. Small fishes of Gullpukurpar and Sankipara Railway Crossing markets were transported mainly from beels. Sometimes, they also collected fish from local fish catches. But in the K-R market retailers collected fish from near the Brahmaputra river and Mohanganj.

Although most of the examined fish of different fish markets were almost normal and healthy from external observation. But histopathologically, it was observed that a notable percentage of fish were affected by EUS and dactylogyrosis. Huge pathological changes were observed in the organs of fish of most of the markets especially collected in December and January. It was observed that environmental condition of Brahmaputhra river and Kailla beel are greatly reduced due to human interference, introduction of surface run off, construction of dams, pollution and introduction of pathogens. This prevails especially in winter season when water level and temperature reduces. Similar observations were made by Palisoc (1990); Chinabut (1994) on EUS outbreaks in the Philippines and Thailand. The reduction of water temperature together with periods of heavy rainfall, low alkalinity and $\mathrm{pH}$ fluctuations were recognized as predisposing factors for the occurrence of EUS (Lilley et al., 1992). Thus steps should be taken from all counterparts to overcome the mentioned problems. Special attention should be given to prevent introduction of pathogen to the beels and rivers. In such ways diseases in fish could be reduced significantly. Moreover, in our country, hygienic condition in the markets was not well developed. Thus hygienic condition of fish markets should be developed in order to avoid contamination of the fishery products transported from 
various harvesting places. In such a way deterioration of health condition of fish in the markets could be protected to a great extent.

\section{REFERENCES}

Ahmed, G. U. and Hoque, M. A. 1999. Mycotic involvement in epizootic ulcerative syndrome of freshwater fishes of Bangladesh. A histopathological study. Asian Fish. Sci., Philippines. 12 : 381-390.

Ahmed, G. U., Hoque, M. M. and Hoque, M. J. 1998. Gill pathology of Juvenile carps in nursery pond. Bangladesh J. Fish. Res., 2(1) : 63-67.

Ahmed, G. U., Nessa, M, Hoque, M. A., Ruksana and Khatun, A. 2000. Investigation of catfish diseases in Mymensingh area through histopathological techniques. Bangladesh J. Fish., 23 (1) : 45-55.

Ahmed, G. U., Parveen, R. and Sultana, S. 2004. Disease investigation of small indigenous fishes from Killa beel in Mymensingh area. J. Bangladesh Agric. Univ., 2(2) : 305-311.

Akter, S., Ahmed, G. U., Roy, M. K. and Akter, N. 2006. Investigation of the disease of small indigenous fish species from Ailee beel. Progress. Agric., 17(1) : 219-225.

Barua, G. 1990. Relationship between epizootic ulcerative syndrome in fish and the environment. Paper submitted in regional research programmer of on relationship between epizootic ulcerative syndrome in fish and the environment, 13-26 August 1990. NACA. Bangkok, Thailand.

Chakma, A. P. 2002. Histopathological observation on the effect of potassium permanganate in curing diseased small indigenous fishes. M. S. Thesis. Department of Aquaculture, Bangladesh Agricultural University, Mymensingh. 65 pp.

Chinabut, S.1995. EUS in Thailand. ODA Regional Seminar on Epizootic Ulcerative Syndrome at Aquatic Animal Health Research Institute, Bangkok, Thailand, January 1994. 58-60 pp.

Felts, R. A., Rajts, F. and Akhteruzzaman, M. 1996. Small indigenous fish species culture in Bangladesh (Technical Brief), IFADEP sub-project-2. Development of inland fisheries. $41 \mathrm{pp}$.

Hatai, K., Nakamura, K., Yuasa, K. and Wada, S. 1994. Aphanomyces infection in Dwarf Gourami (Colisa lalia). Fish Pathol., 29(2) : 95-99.

Islam, M. J., Ahmed, G. U., Islam, T., Haque, M. A. and Sarker, M. G. A. 1999. Gill pathology of carps disease from farming system of Bangladesh. Bangladesh J. Fish., 22(2) : 113-118.

Khan, M. A. R. 1995. Fish marketing in some selected areas of Bangladesh. M. S. Thesis, Department of Co-operative and Marketing, Bangladesh Agricultural University, Mymensingh. 65 pp.

Kumar, D., Dey, R. K. and Sinha, A. 1991. Outbreak of epizootic ulcerative syndrome of fish in India. pp. 345-365, in V. R. P Sinha and H. D. Sriva (ed), Aquaculture Productivity Lever Research Foundation.

Lilley, J. H., Phillips, M. J. and Tonguthai, K. (1992). A review of epizootic ulcerative syndrome (EUS) in Asia. Aquatic Animal Health Research Institute and Network of Aquaculture Centers in Asia-Pacific, Bangkok, Thailand. 73 pp.

Moniruzzam, M. 2000. Investigation on disease of some small indigenous freshwater fishes of Bangladesh. M. S. Thesis. Department of Aquaculture, Bangladesh Agricultural University, Mymensingh. 80 pp. 
Monowara, M. 2003. Monogenean infestation on certain small indigenous fishes of Mymensingh. M. S. Thesis. Department of Department of Aquaculture, Bangladesh Agricultural University, Mymensingh. 144 pp.

Noga, E. J. and Dykstra, M. J. 1986. Ooymcete fungi associated with ulcerative mycosis in menhaden Brevoortia tyrannus (Loatrobe). J. Fish Dis., 9 : 47-53.

Palisoc, F. P. 1990. Philippines Report, pp. 45-417. In: Regional Research Programme on Relationships between Epizootic Ulcerative Syndrome in Fish and the Environment, 13-25 August 1990. NACA. Bangkok.

Parveen, R. 2001. Disease investigation of three small indigenous fishes from beels of Mymensingh. M. S. Thesis. Department of Aquaculture, Bangladesh Agricultural University, Mymensingh. 77 pp.

Roy, M. K., Ahmed, G. U., Akter, S. and Akter, N. 2006. Study of health condition of small indigenous freshwater fishes of Ailee beel. Progress. Agric., 17(1) : 201-209.

Ram, R. N. and Singh, S. K. 1988. Carbofuran induced histopathological and biochemical changes in liver of the teleost fish, Channa punctatus (Bloch). Ecotox. Environ. Safety, 16(3) : 194-201.

Thilsted, S. H., Roos, N. and Hasan, N. 1997. The role of small indigenous fish species in food and nutrition security in Bangladesh. NAGA News letter, July-Dec., 13 pp.

Tripathi, S. D. 1997. The role of fisheries and Aquaculture in improving the food and nutrition security in Bangladesh. Paper presented at the Training workshop in food nutrition security in Bangladesh. Organized by BRRI and ENRECA project, 12 March 1997, Bangladesh. 